\title{
Perancangan Struktur Metode Student Centre Learning (SCL) Dalam Mata Kuliah Sistem Akuntansi Dengan Kurikulum Berbasis Kompetensi (KBK)
}

\author{
Zahara \\ Zalida Afni \\ Jurusan Akuntansi Politeknik Negeri Padang
}

\begin{abstract}
This research porpuse to design the structure of Student Centre Learning (SCL) methode in accounting system subject that use curriculum based on competency. This is an action research in accounting system study at accounting departement of Padang State Polytechnic. This research uses Kemmis dan Mac Tanggart model which is devided in 5 steps that are: 1. Planning, 2. Action\&Observation, 3. Reflecting\&Replanning, 4. Action\&Observation and 5. Reflecting. The application of SCL metode in accounting system study will be evaluated based on the score of studying observation, student respons and student score academic in accounting system. The observation and student respons questioners are measured by Linkert scale for 5 level as well as student academic score there are: $5=A=$ Very Good, $4=B=$ Good, $3=C=E n o u g h t, 2=D=B a d$, and $1=E=$ Very Bad. All of score data will be process by SPSS package program to define the appropriateness of SCL methode for accounting system subject. This research is still going on to the second step. There are 5 SCL model that chosen as the result of the first step research (planning) i.e. Small Group Discussion, Discovery Learning, Role Play, Contextual Instruction dan Problem Based Learning.
\end{abstract}

Key words : Student Centre Learning (SCL) method, accounting system, Small Group Discussion, Discovery Learning, Role Play, Contextual Instruction dan Problem Based Learning

\section{PENDAHULUAN}

Metode Student Centre Learning (SCL) merupakan metode yang paling cocok digunakan dalam pencapaian tujuan perkuliahan dalam Kurikulum Berbasis Kompetensi (KBK). Mata kuliah Sistem Akuntansi adalah salah satu mata kuliah wajib pada Program Studi (Prodi) D3 dan Prodi D4 Jurusan Akuntansi Politeknik Negeri Padang yang telah menerapkan KBK. Mata kuliah ini merupakan mata kuliah dasar dari rangkaian mata kuliah Sistem Informasi Akuntansi dan Praktek Kerja Akuntansi (PKA)/Terapan Sistem Informasi Akuntansi pada kedua prodi. Sehingga penguasaan mahasiswa terhadap kemampuan keilmuan (hardskill) dan keterampilan (softskill) mata kuliah Sistem
Akuntansi ini sangat penting dan mempengaruhi penguasaan mata kuliah lanjutannya.

Selain menjadi landasan untuk mata kuliah lanjutannya, materi yang dipelajari dalam mata kuliah sistem akuntansi ini hampir semuanya memiliki keterkaitan dan bersinergi dengan materi pada mata kuliah inti akuntansi lainnya seperti dengan mata kuliah akuntansi keuangan, akuntansi biaya, akuntansi manajemen, pemeriksaan akuntansi (auditing) dan perpajakan. Sehingga mata kuliah sistem akuntansi ini juga dapat menjadi mata rantai nilai (value chain) penghubung antara berbagai mata kuliah inti akuntansi, dimana proses belajar mengajar yang tepat akan sangat membantu mahasiswa dalam membangun kepahaman yang sistematis dan komprehensif 
Perancangan Struktur Metode Student Centre Learning (SCL) Dalam Mata Kuliah Sistem Akuntansi ...

terhadap keilmuan dan praktik akuntansi secara umum.

Berdasarkan kondisi ini kebutuhan terhadap metode belajar mengajar yang paling tepat untuk mata kuliah sistem akuntansi dengan KBK ini sangat diperlukan. Maka penelitian ini akan mencoba memenuhi kebutuhan tersebut dengan merumuskan masalah: "Bagaimanakah rancangan struktur metode SCL untuk mata kuliah Sistem Akuntansi dalam KBK?". Hasil penelitian ini diharapkan akan menyediakan "rancangan struktur metode SCL yang optimal untuk mata kuliah Sistem Akuntansi yang berbasis KBK". Metode belajar yang tepat dalam mata kuliah sistem akuntansi ini akan membangun dan meningkatkan hardskill dan softskill mahasiswa dalam mata kuliah sistem akuntansi pada khususnya dan pemahaman yang komprehensif dan terintegrasi tentang ilmu serta praktik akuntansi pada umumnya.

\section{KAJIAN LITERATUR} Gambaran Umum Materi Sistem Akuntansi
Materi dalam mata kuliah sistem akuntansi terbagi atas 2 (dua) bagian utama yaitu perancanan sistem akuntansi pokok dan sistem akuntansi pendukung. Dalam sistem akuntansi pokok akan dibahas tentang perancangan formulir bukti transaksi dan media pencatatan data tersebut untuk penyajian informasi akuntansi. Sedangkan dalam sistem akuntansi pendukung akan dibahas contoh-contoh rangkaian prosedur dalam sistem akuntansi yang sesuai untuk menghasilkan bukti transaksi tersebut. Dalam setiap tahapan proses perancanan tersebut tidak lepas dari unsur pengendalian intern untuk memastikan bahwa prosedur berjalan sebagaimana seharusnya sehingga semua data yang direkam dan dicatat dalam media adalah data yang benar dan valid yang diproses dengan prosedur yang benar untuk menjamin kebenaran dan vaiditas informasi akuntansi yang dihasilkan.

Secara umum rangkaian materi dalam mata kuliah sistem akuntansi dapat dilihat dalam diagram rerangka materi berikut :

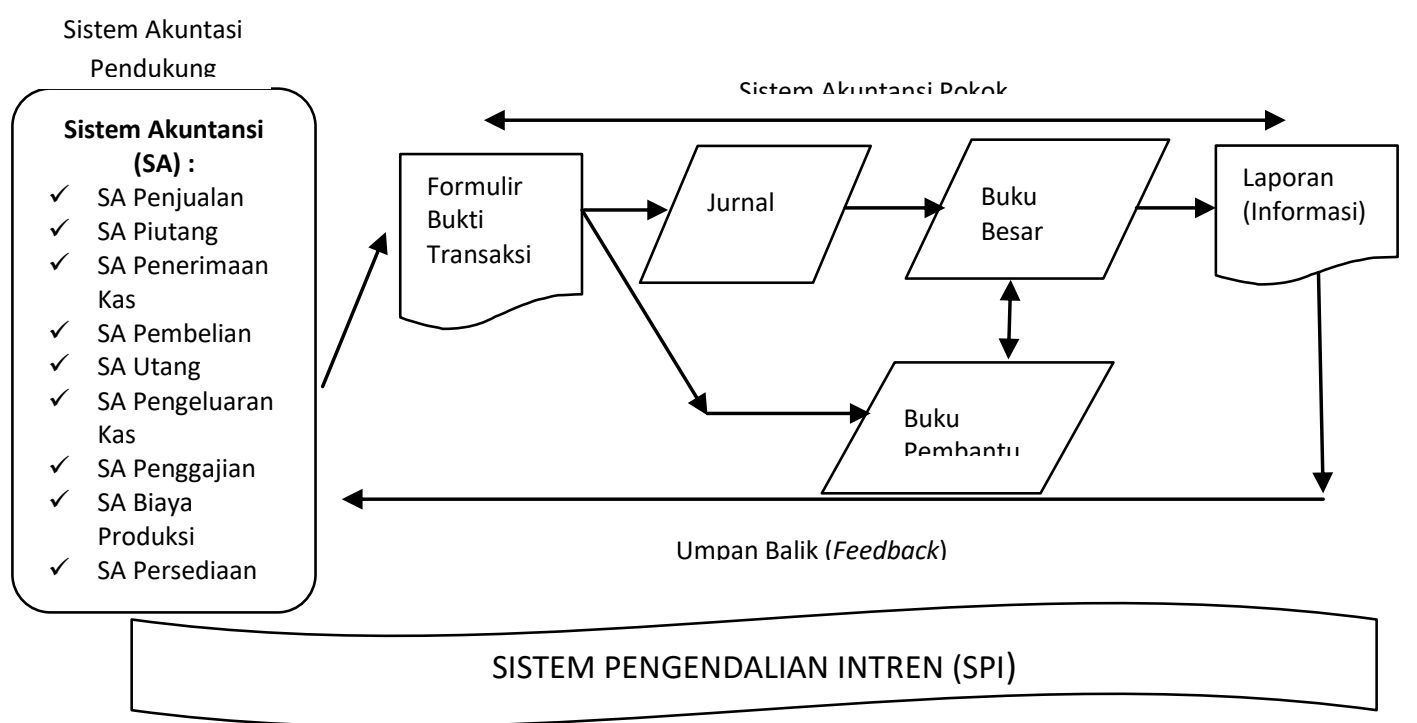

Gambar 1. Rerangka Sistem Akuntansi

Sumber: Adaptasi Rerangka Sistem Akuntansi (Mulyadi, 2001)

Dari rerangka materi mata kuliah sistem akuntansi diatas terlihat bahwa dalam mata kuliah sistem akuntansi ini mahasiswa tidak hanya belajar tentang perancangan komponen-komponen sistem akuntansi pokok tetapi juga mempelajari contoh-contoh berbagai sistem akuntansi pendukung yang terdapat dalam suatu perusahaan. Dimana 
Perancangan Struktur Metode Student Centre Learning (SCL) Dalam Mata Kuliah Sistem Akuntansi ...

sistem akuntansi pendudukung ini merupakan rangkaian prosedur untuk manangani setiap transaksi perusahaan yang menghasilkan data transaksi yang akan diolah dalam sistem akuntansi pokok mulai dari pencatatan sampai kepada pelaporan transaksi tersebut. Sehingga dalam mata kuliah sistem akuntansi ini, mahasiswa akan mempelajari kegiatan akuntansi tersebut secara terintegrasi dan komprehensif.

Dalam mata kuliah sistem akuntansi, materi sistem akuntansi pokok yang merupakan inti kegiatan utama dalam akuntansi secara umum, hal ini bersinergi dengan materi dalam mata kuliah akuntansi keuangan dan komputer akuntansi. Materi sistem akuntansi pendukung yang membahas tentang sistem akuntansi penjualan, piutang, penerimaan kas, pembelian, utang dan pengeluaran kas yang terkait dengan transaksi penjualan dan pembelian perusahaan yang dikenai pajak, terkait dengan mata kuliah perpajakan. Sistem akuntasi biaya produksi yang membahas tentang prosedur pelaksanaan produksi perusahaan sangat terkait dengan mata kuliah akuntansi biaya. Materi sistem akuntansi penggajian, persediaan dan aktiva tetap lebih memfokuskan kepada efesiensi biaya dalam setiap aktifitas pembiayaan terkait yang sangat erat dengan materi dalam akuntansi manajemen. Sedangkan materi sistem pengendalian intern (SPI) yang merupakan alat kontrol dan menjadi alat ukur kelayakan suatu sistem akuntansi yang terdapat dalam setiap muatan materi sistem akuntansi tersebut merupakan alat kontrol yang sama yang digunakan dalam mata kuliah pemeriksaan akuntansi (auditing).

Pengajaran mata kuliah Sistem Akuntansi yang mengandung muatan materi yang cukup luas dan terintegrasi dengan mata kuliah lainnya menjadi tantangan tersendiri dalam merangkai mata kuliah ini menjadi menarik bagi mahasiswa. Membahas sisi lain dari konten materi yang hampir sama dengan materi pada mata kuliah lain juga membutuhkan strategi untuk memancing keinginan mahasiswa untuk memahami materi tersebut secara komprehensif. Disinilah peranan metode pembelajaran SCL yang tepat yang ditunjang dengan paket modul ajar yang sesuai untuk dapat memotivasi mahasiswa belajar dan memahami materi kuliah sistem akuntansi ini dengan lebih baik guna membangun hardskill dan softskill mereka yang komprehensif.

\section{Kurikulum Berbasis Kompetensi (KBK)}

Definisi kurikulum menurut Kepmendiknas No.232/U/2000 berbunyi : Kurikulum adalah seperangkat rencana dan pengaturan mengenai isi maupun bahan kajian dan pelajaran serta cara penyampaiannya dan penilaiannya yang digunakan sebagai pedoman penyelenggaraan kegiatan belajar mengajar di perguruan tinggi. Pengembangan kurikulum merupakan bagian yang paling inti dari sederet pengembangan tata kelola sistem pendidikan tinggi di tingkat program studi, dalam upaya penyesuaian terhadap perkembangan standard kompetensi bidang kerja di dunia industri, penyesuaian tehadap perkembangan teknologi global, atau adanya kebijakan institusi terkait dengan tuntutan pergeseran visi misi serta norma yang berkembang di masyarakat (Rahmat, 2011).

Kompetensi adalah seperangkat tindakan cerdas, penuh tanggungjawab yang dimiliki seseorang sebagai syarat untuk dianggap mampu oleh masyarakat dalam melaksanakan tugas-tugas di bidang pekerjaan tertentu.(SK Mendiknas No. 045/U/2002, Ps. 21), dengan elemen kompetensi sebagai berikut : (a) Landasan kepribadian, (b) Penguasan ilmu dan ketrampilan, (c) Kemampuan berkarya, (d) Sikap dan perilaku dalam berkarya dan (e) Pemahaman kaidah berkehidupan bermasyarakat. Perubahan yang sangat cepat di semua sektor kehidupan khususnya dunia kerja, mendorong perguruan tinggi membekali lulusannya dengan kemampuan adaptasi dan kreatifitas yang dapat bersaing dalam dunia global, dapat menerapkan ilmunya dimasyarakat (kompeten), dapat memenuhi perubahan persyaratan dunia kerja yaitu softskills yang dominan disamping hardskills, sehingga nantinya lulusan perguruan tinggi dapat hendaknya mengikuti perubahan dan perkembangan yang cepat. Mengacu pada konsep pendidikan tinggi abad XXI UNESCO (1998), dilakukan pembaharuan terhadap kurikulum yang telah berjalan (Kurikulum SK Mendikbud No.056/U/1996) yaitu Kurikulum Berbasis Isi/KBI, menjadi Kurikulum Berbasis 
Perancangan Struktur Metode Student Centre Learning (SCL) Dalam Mata Kuliah Sistem Akuntansi ...

Kompetensi/KBK, yang dituangkan dalam SK mendiknas No.232/U/2000 dan No.045/U/2002.

Perubahan kurikulum juga berarti perubahan proses pembelajaran. Artinya, proses pembelajarannya tidak hanya merupakan suatu proses alih pengetahuan (transfer of knowledge), tapi juga merupakan suatu proses pembekalan yang berupa metoda inquiry/penggalian (method of inquiry) seseorang yang kompeten dalam berkarya di masyaraka (Buku KPT, Dikti,2012). Sehingga tujuan akhir dari penyusunan kurikulum berbasis kompetensi adalah tercapainya kompetensi lulusan yang sesuai atau mendekati kebutuhan kompetensi di dunia kerja.

Untuk mengoptimalkan penerapan kurikulum berbasis kopetensi ini dibutuhkan metode pembelajaran yang sesui untuk mengoptimalkan proses belajar belajar yang dilakukan. Metode yang dianggap paling tepat untuk penerapan kurikulum berbasis kompetensi ini adalah metode student centred learning (SCL). Dimana dalam pembelajaran SCL tidak hanya menekankan pada hasil belajar, tetapi juga pada proses belajar untuk membentuk kompetensi mahasiswa, sehingga capaian pembelajaran tersebut dapat terpenuhi.

\section{Pembelajaran dengan Metode Student Centred Learning (SCL)}

Menurut Undang-Undang Sistem Pendidikan Nasional (SISDIKNAS) Nomor 20 Tahun 2003; Pasal 1 , ayat 1 pengertian pendidikan adalah "usaha sadar dan terencana untuk mewujudkan suasana belajar dan proses pembelajaran agar peserta didik secara aktif mengembangkan potensi dirinya untuk memiliki kekuatan spiritual keagamaan, pengendalian diri, kepribadian, kecerdasan, akhlak mulia, serta keterampilan yang diperlukan dirinya, masyarakat, bangsa dan negara". Sistem pendidikan tinggi di Indonesia memiliki 4 (empat) tahapan pokok yaitu (1) Masukan (Input); (2).Proses; (3).Keluaran (output); (4).Dampak (outcome). Oleh karena itu untuk menghasilkan lulusan yang berkualitas, pendidikan tinggi harus melakukan proses pembelajaran yang baik. Pembelajaran yang dimaksud adalah interaksi antara pendidik, peserta didik, dan sumber belajar, didalam lingkungan belajar tertentu. Sehingga dengan mendeskripsikan setiap unsur yang terlibat dalam pembelajaran tersebut dapat ditengarai ciri pembelajaran yang berpusat pada siswa (student centered learning).

Sistem pembelajaran yang baik mampu memberikan pengalaman belajar kepada mahasiswa untuk membuka potensi dirinya dalam menginternalisasikan pengetahuan, keahlian, dan perilaku serta pengalaman belajar sebelumnya, dan merupakan bagian penting untuk mampu menghasilkan lulusan yang berdaya saing tinggi. Sistem pembelajaran seperti itu mampu mengembangkan elemen-elemen kompetensi yang diamanatkan oleh Kepmendiknas No. 045/2002. Dengan dikeluarkannya Perpres No. 8 Tahun 2012 tentang Kerangka Kualifikasi Nasional Indonesia (KKNI), program studi pada perguruan tinggi dituntut untuk menghasilkan lulusan yang sesuai dengan kualifikasi KKNI.Dengan demikian bagi Perguruan Tinggi yang masih bermasalah di dalam sistem pembelajarannya mesti segera melakukan pembenahan atau perbaikan untuk mampu menghasilkan lulusan paling tidak memenuhi kualifikasi yang telah ditetapkan.

Proses pembelajaran pada dasarnya merupakan pemberian stimulus-stimulus kepada mahasiswa, agar terjadinya respons yang positif pada diri anak didik. Kesediaan dan kesiapan mereka dalam mengikuti proses demi proses dalam pembelajaran akan mampu menimbulkan respons yang baik terhadap stimulus yang mereka terima dalam proses pembelajaran (Arifin,2010). Pada sistem pembelajaran SCL mahasiswa dituntut aktif mengerjakan tugas dan mendiskusikannya dengan dosen sebagai fasilitator. Dengan aktifnya mahasiswa, maka kreativitas mahasiswa akan terpupuk. Kondisi tersebut akan mendorong dosen untukselalu mengembangkan dan menyesuaikan materi kuliahnya dengan perkembangan IImu Pengetahuan danTeknologi (IPTEK). Dengan diterapkannya sistem pembelajaran SCL diharapkan mahasiswa aktif dan kreatif, menyelesaikan tugas akhir dengan lancar/cepat, dengan harapan mahasiswa dapat menyelesaikan studi dengan lancar dan tepat waktu sesuai dengan target atau bahkan bisa lebih cepat dari standar waktu masa studi. Selanjutnya mahasiswa setelah lulus 
Perancangan Struktur Metode Student Centre Learning (SCL) Dalam Mata Kuliah Sistem Akuntansi ...

diharapkan mampu berkompetisi didunia kerja.

(Sari dan Ali 2010).

Beberapa metode pembelajaran
dengan SCL, (Dewajani, 2008) yaitu :

Tabel.1 Metode Pembelajaran dengan Student Centre Learning (SCL)

\begin{tabular}{|c|l|l|l|}
\hline No & $\begin{array}{c}\text { MODEL } \\
\text { BELAJAR }\end{array}$ & \multicolumn{1}{|c|}{$\begin{array}{c}\text { YANG DILAKUKAN } \\
\text { MAHASISWA }\end{array}$} & YANG DILAKUKAN DOSEN \\
\hline 1 & $\begin{array}{l}\text { Small Group } \\
\text { Discussion }\end{array}$ & $\begin{array}{l}\text { - membentuk kelompok (5-10) } \\
\text { - memilih bahan diskusi } \\
\text { mepresentasikan paper dan } \\
\text { mendiskusikan di kelas }\end{array}$ & $\begin{array}{l}\text { - Membuat rancangan bahan } \\
\text { dikusi dan aturan diskusi. } \\
\text { - Menjadi moderator dan sekaligus } \\
\text { mengulas pada setiap akhir } \\
\text { sesion diskusi mahasiswa. }\end{array}$ \\
\hline 2 & Simulasi & $\begin{array}{l}\text { - mempelajari dan menjalankan } \\
\text { suatu peran yang ditugaskan } \\
\text { kepadanya. } \\
\text { - atau mempraktekan/mencoba } \\
\text { berbagai model (komputer) } \\
\text { yang telah disiapkan. }\end{array}$ & $\begin{array}{l}\text { - Merancang situasi/ kegiatan yang } \\
\text { mirip dengan yang } \\
\text { sesungguhnya, bisa berupa } \\
\text { bermain peran, model komputer, } \\
\text { atau berbagai latihan simulasi. } \\
\text { - Membahas kinerja mahasiswa. }\end{array}$ \\
\hline 3 & Discovery & $\begin{array}{l}\text { Mencari, mengumpulkan, dan } \\
\text { menyusun informasi yang ada } \\
\text { untuk mendeskripsikan suatu } \\
\text { pengetahuan. }\end{array}$ & $\begin{array}{l}\text { Menyediakan data, atau petunjuk } \\
\text { (metode) untuk menelusuri suatu } \\
\text { pengetahuan yang harus } \\
\text { dipelajari oleh mahasiswa. } \\
\text { - Memeriksa dan memberi ulasan } \\
\text { terhadap hasil belajar mandiri } \\
\text { mahasiswa. }\end{array}$ \\
\hline
\end{tabular}




\begin{tabular}{|c|l|l|l|}
\hline No & \multicolumn{1}{|c|}{$\begin{array}{c}\text { MODEL } \\
\text { BELAJAR }\end{array}$} & \multicolumn{1}{|c|}{$\begin{array}{c}\text { YANG DILAKUKAN } \\
\text { MAHASISWA }\end{array}$} & YANG DILAKUKAN DOSEN \\
\hline 4 & $\begin{array}{l}\text { Self-Directed } \\
\text { Learning }\end{array}$ & $\begin{array}{l}\text { - merencanakan kegiatan } \\
\text { belajar, melaksanakan, dan } \\
\text { menilai pengalaman } \\
\text { belajarnya sendiri. }\end{array}$ & • sebagai fasilitator. \\
\hline 5 & $\begin{array}{l}\text { Cooperative } \\
\text { Learning }\end{array}$ & $\begin{array}{l}\text { - Membahas dan } \\
\text { menyimpulkan masalah/ } \\
\text { tugas yang diberikan dosen } \\
\text { secara berkelompok. }\end{array}$ & $\begin{array}{l}\text { - merancang dan dimonitor proses } \\
\text { belajar dan hasil belajar } \\
\text { kelompok mahasiswa. } \\
\text { - Menyiapkan suatu masalah/ } \\
\text { kasus atau bentuk tugas untuk } \\
\text { diselesaikan oleh mahasiswa } \\
\text { secara berkelompok. }\end{array}$ \\
\hline 6 & $\begin{array}{l}\text { Collaborative } \\
\text { Learning }\end{array}$ & $\begin{array}{l}\text { - Bekerja sama dengan } \\
\text { anggota kelompoknya dalam } \\
\text { mengerjakan tugas } \\
\text { - Membuat rancangan proses } \\
\text { dan bentuk penilaian } \\
\text { berdasarkan konsensus } \\
\text { kelompoknya sendiri. }\end{array}$ & $\begin{array}{l}\text { - Merancang tugas yang bersifat } \\
\text { open ended. } \\
\text { Sebagai fasilitator dan motivator. }\end{array}$ \\
\hline
\end{tabular}

\begin{tabular}{|c|l|l|l|}
\hline No & $\begin{array}{c}\text { MODEL } \\
\text { BELAJAR }\end{array}$ & \multicolumn{1}{|c|}{$\begin{array}{c}\text { YANG DILAKUKAN } \\
\text { MAHASISWA }\end{array}$} & BENTUK KEGIATAN BELAJAR \\
\hline 7 & $\begin{array}{l}\text { Contextual } \\
\text { Instruction }\end{array}$ & $\begin{array}{l}\text { - Membahas konsep (teori) } \\
\text { kaitannya dengan situasi } \\
\text { nyata } \\
\text { - Melakukan studi lapang/ } \\
\text { terjun di dunia nyata untuk } \\
\text { mempelajari kesesuaian } \\
\text { teori. }\end{array}$ & $\begin{array}{l}\text { - Menjelaskan bahan kajian yang } \\
\text { bersifat teori dan mengkaitkannya } \\
\text { dengan situasi nyata dalam } \\
\text { kehidupan sehari-hari, atau kerja } \\
\text { profesional, atau manajerial, atau } \\
\text { entrepreneurial. } \\
\text { - Menyusun tugas untuk studi } \\
\text { mahasiswa terjun ke lapangan }\end{array}$ \\
\hline 8 & $\begin{array}{l}\text { Project } \\
\text { Based } \\
\text { Learning }\end{array}$ & $\begin{array}{l}\text { - Mengerjakan tugas (berupa } \\
\text { proyek)yang telah } \\
\text { dirancang secara } \\
\text { sistematis. } \\
\text { - Menunjukan kinerja dan } \\
\text { mempertanggung jawabkan } \\
\text { hasil kerjanya di forum. }\end{array}$ & $\begin{array}{l}\text { - Merancang suatu tugas (proyek) } \\
\text { yang sistematik agar mahasiswa } \\
\text { belajar pengetahuan dan ketrampilan } \\
\text { melalui proses pencarian/ } \\
\text { penggalian (inquiry), yang terstruktur } \\
\text { dan kompleks. } \\
\text { - Merumuskan dan melakukan proses } \\
\text { pembimbingan dan asesmen. }\end{array}$ \\
\hline 9 & $\begin{array}{l}\text { Problem } \\
\text { Based } \\
\text { Learning }\end{array}$ & $\begin{array}{l}\text { - Belajar dengan menggali/ } \\
\text { mencari informasi (inquiry) } \\
\text { serta memanfaatkan } \\
\text { informasi tersebut untuk } \\
\text { memecahkan masalah } \\
\text { faktual/yang dirancang } \\
\text { oleh dosen }\end{array}$ & $\begin{array}{l}\text { - Merancang tugas untuk mencapai } \\
\text { kompetensi tertentu } \\
\text { - Membuat petunjuk(metode) untuk } \\
\text { mahasiswa dalam mencari } \\
\text { pemecahan masalah yang dipilih } \\
\text { oleh mahasiswa sendiri atau yang } \\
\text { ditetapkan. }\end{array}$ \\
\hline
\end{tabular}


Perancangan Struktur Metode Student Centre Learning (SCL) Dalam Mata Kuliah Sistem Akuntansi ...

Dari berbagai metode $\mathrm{SCl}$ diatas terlihat dosen dan mahasiswa terlibat aktif dan mempunyai peran masing-masing dalam pembelajaran. Peran dosen antara lain : (1) Sebagai fasilitator dalam proses pembelajaran, (2) Mengkaji kompetensi mata kuliah yang perlu dikuasai mahasiswa pada akhir pembelajaran, (3) Merancang strategi dan lingkungan pembelajaran yang dapat menyediakan beragam pengalaman belajar yang diperlukan mahasiswa dalam rangka mencapai kompetensi yang dituntut mata kuliah, (4) Membantu mahasiswa mengakses, menata, dan memprosesi informasi untuk dimanfaatkan dalam memecahkan permasalahan hidup sehari-hari, dan (5) Mengidentifikasi dan menentukan pola penilaian hasil belajar mahasiswa yang relevan dengan kompetensi yang akan diukur. Sedangkan mahasiswa yang juga harus terlibat aktif dalam sistem pembelajaran SCL ini mahasiswa juga mempunyai peran antara lain : (1) Mengkaji

Model ini menunjukkan penelitian dilakukan dalam 2 (dua) siklus yang
masing-masing terdiri atas 3 kegiatan. Siklus 1 terdiri dari (a) plan
(perencanaan) yaitu penyusunan perencanaan tindakan kelas; (b) act \&
observe (tindakan dan observasi) yaitu pelaksanaan penelitian tindakan
kelas, observasi dan perekaman data respon partisipan/sasaran
(responden); (c) reflect (evaluasi) yaitu analisis hasil penelitian. Hasil
evaluasi dari siklus 1 ini akan bahan masukan untuk perbaikan yang akan
dilakukan dalam siklus ke 2 dengan kegiatan yang sama yaitu: (a) replan
(perencanaan ulang) sesuai hasil evaluasi siklus 1; (b) act \& observe
(tindakan dan observasi) tindakan perbaikan dan observasi respon
partisipan terhadap perbaikan tersebut; (c) reflect (evaluasi) analisis
perbaikan untuk luaran penelitian yang diharapkan.

Gambar 2. Bagan Penelitian Tindakan Kelas Model Kemmis dan MacTaggart

Berdasarkan adatasi terhadap model diatas, penelitian ini akan dibagi kedalam 5 tahapan utama yaitu :

Tahap I Perencanaan (Planning) berisi kegiatan untuk penyusunan rancangan struktur metode SCL yang akan digunakan dan penyusunan draf paket modul ajar yang sesuai dengan metode SCL yang digunakan serta perancangan kuisioner observasi untuk perekaman data respon mahasiswa terhadap metode SCL dan paket modul ajar yang digunakan dan persiapan alat bantu yang dibutuhkan untuk pelaksanaan tindakan kelas. kompetensi mata kuliah yang dipaparkan dosen, (2) Mengkaji strategi pembelajaran yang ditawarkan dosen, (3) Menbuat rencana pembelajaran untuk mata kuliah yang diikutinya dan (4) Belajar secara aktif (dengan cara mendengar, membaca, menulis, diskusi, dan terlibat dalam pemecahan masalah serta lebih penting lagi terlibat dalam kegiatan berfikir tingkat tinggi, seperti analisis, sintesis, dan evaluasi), baik secara individual maupun berkelompok. Dengan keterlibatan aktif mahasiswa dalam proses pembelajaran ini diharapkan akan diperoleh hasil belajar yang lebih baik.

\section{METODE PENELITIAN}

Penelitian ini bersifat action research dalam bentuk tindakan kelas yang mengacu kepada model Kemmis dan MacTaggart (Amirin,2009) seperti bagan berikut : 
Perancangan Struktur Metode Student Centre Learning (SCL) Dalam Mata Kuliah Sistem Akuntansi ...

terhadap data-data observasi serta evaluasi hasil penelitian terhadap tujuan penelitian. Hasil analsis dan evaluasi ini akan menjadi bahan untuk perencanaan ulang terhadap perbaikan rancangan struktur metode $\mathrm{SCL}$ yang disusun dan paket modul ajar.

Tahap IV Tindakan dan Pengamatan (Action \& Observation) merupakan penerapan perbaikan rancangan struktur metode SCL dan paket modul ajar. Palaksanaan perbaikan tindakan kelas ini dilakukan pada tahun kedua dalam kuliah Sistem Akuntansi untuk 18 kali pertemuan. Observasi dan perekaman data juga dilakukan untuk setiap pertemuan.

Tahap V Analisis Akhir Penelitian (Reflecting), merupakan pengolahan dan analisis data hasil observasi tahap IV atas perbiakan yang telah dilakukan, sehingga diperoleh rancangan struktur metode SCL yang paling optimal untuk mata kuliah sistem akuntansi dengan KBK ini.

Variabel Penelitian dan Pengukurannya

Variabel yang digunakan dalam menilai keberhasilan penelitian ini adalah : (1) respon mahasiswa partisipan terhadap rancangan struktur metode SCL dan paket modul ajar yang telah dirancang dan digunakan dalam tindakan kelas (2) nilai mata kuliah sistem akuntansi mahasiswa partisipan. Gabungan nilai akhir dari respon mahasiswa dan nilai mata kuliah sistem akuntansi yang mereka peroleh akan menjadi indikator optimal atau tidaknya rancangan struktur metode SCL untuk mata kiah sistem akuntansi dengan KBK dalam penelitian ini.

Data respon mahasiswa partisipan yang diobservasi dikumpulkan dengan menggunakan kuisioner yang dibagikan kepada mahasiswa setiap selesai perkuliahan. Reliabilitas dan validitas kuisioner diuji dengan teknik Pilot Testing. Pernyataan dalam kuisioner tentang metode SCL dan paket modul ajar yang digunakan, akan diukur dengan skala Likert dengan rentang nilai 1-5 untuk megukur apakah metode SCL dan paket modul ajar yang digunakan dapat meningkatkan kemampuan hardskill dan sofskill mereka dalam mata kuliah sistem akuntansi. Sedangkan data nilai mata kuliah mahasiswa partisipan diperoleh dari nilai latihan, tugas, kuis dan ujian baik ujian tengah semester maupun ujian akhir semester yang diberikan selama perkulihan Sistem Akuntansi berlangsung. Nilai akhir mahasiswa diukur dengan angka mutu dari A-E sesuai dengan peraturan akademik PNP.

Pengolahan data penelitian ini menggunakan program SPSS, dimana nilai akhir gabungan dari nilai respon mahasiswa nilai Sistem Akuntansi mereka akan menjadi indikator baik atau tidaknya rancangan struktur metode SCL yang digunakan dalam perkuliahan sistem akuntansi dengan KBK ini. Standar penilaian ini mengacu kepada standar Angka dan Nilai Mutu yang digunakan dalam peraturan Akademik PNP sebagai standar pengukuran hasil penelitian yaitu :

Tabel 2. Konversi Nilai Data dalam Pengukuran Hasil Henelitian

\begin{tabular}{|c|c|c|c|}
\hline $\begin{array}{c}\text { Nilai Respon } \\
\text { Mahasiswa }\end{array}$ & $\begin{array}{c}\text { Nilai Akhir Sistem } \\
\text { Akuntansi }\end{array}$ & Angka Mutu & Nilai Mutu \\
\hline 5 & $81-100$ & A & Sangat Baik \\
\hline 4 & $66-80$ & B & Baik \\
\hline 3 & $56-65$ & C & Cukup \\
\hline 2 & $41-55$ & D & Kurang \\
\hline 1 & $0-40$ & E & Sangat Kurang \\
\hline
\end{tabular}

Sumber : Peraturan Akademik Politeknik Negeri Padang

\section{HASIL DAN PEMBAHASAN}

Penelitian ini baru selesai pada tahap 1 yaitu perencanaan (planning). Hasil dari tahap 1 ini adalah tersedianya rancangan susunan metode Student Centre Learning (SCL) untuk mata kuliah Sistem Akuntansi dengan Kurikulum Berbasis Kompetensi (KBK) untuk 18 kali pertemuan. Dari berbagai alternatif metode SCL yang biasa digunakan dalam pembelajaran, dipilih beberapa metode $\mathrm{SCL}$ 
Perancangan Struktur Metode Student Centre Learning (SCL) Dalam Mata Kuliah Sistem Akuntansi ...

yang diperkirakan paling sesuai dengan muatan materi dalam mata kuliah Sistem Akuntansi dan membantu mahasiswa dalam penguasaan kemampuan keilmuan dan praktik baik dalam bentuk hardskill maupun softskill yang ditargetkan.

Pada penelitian tahap 1 ini analisis yang dilakukan bersifat deskriptif kualitatif, dimana pemilihan metode SCL didasarkan kepada karakteristik metode SCL dan sifat kanten materi yang akan disajikan dalam setiap pertemuan perkuliahan sistem akuntansi, serta hasil pengamatan terhadap pengajaran sistem akuntansi selama ini. Secara umum sifat materi yang akan disajikan dalam mata kuliah akuntansi

cukup beragam. Ada konten materi yang dominan bersifat teori, dimana mahasiswa harus membaca materi tersebut dengan baik beserta contoh aplikasinya sehingga terbangun pemahaman yang utuh bagi mereka terhadap materi tersebut. Untuk materi yang bersifat seperti ini digunakan metode Small Group Discussion.

Materi yang kontennya terkait perancangan format dokumen dan catatan akuntansi, membutuhkan pengetahuan dan kemampuan analisis mahasiswa untuk merancang berbagai format media perekaman data sesuai dengan variasi kebutuhan informasi perusahaan. Untuk materi ini digunakan metode Discovery Learning yang dikombinasi dengan tugas terstruktur dan tugas kasus sederhana.

Pada materi yang berisi contoh-contoh sistem akuntasi pendukung yag ada di perusahaan dapat digunakan beberapa metode SCL seperti Role Play, Contextual Instruction, dan Prablem Based Learning. Pada materi ini mahasiswa akan mempelajari berbagai contoh ideal sistem akuntansi pendukung yang ada di perusahaan untuk nantinya bisa menjadi panduan bagi mahasiswa untuk dapat merancang sendiri berbagai sistem akuntansi pendukung lainnya sesuai dengan karakteristik dan kebutuhan perusahaan yang berbeda-beda.

Setiap metode SCL yang digunakan tetap dapat dikombinasi dengan ceramah untuk pengantar materi, simpulan materi ataupun pembahasan tugas dan kasus yang diberikan. Hal ini sejalan dengan peran dosen selaku pembimbing ataupun fasilitator bagi mahasiswa. Berikut gambaran umum rancangan struktur metode Student Centre Learning (SCL) untuk mata kuliah Sistem Akuntansi dengan Kurikulum Berbasis Kompetensi (KBK)

Tabel 3. Rancangan Struktur Metode SCL untuk mata kuliah Sistem Akuntansi dengan KBK

\begin{tabular}{|c|c|c|c|c|}
\hline No & Metode SCL & Materi Ajar & Format Tugas & Keterangan \\
\hline 1. & $\begin{array}{l}\text { Ceramah dan } \\
\text { Tanya Jawab }\end{array}$ & $\begin{array}{ll}\checkmark & \text { Gambaran umum } \\
& \text { perkuliahan } \\
\checkmark & \text { Sistem Penilaian } \\
\checkmark & \text { Gambaran materi dan } \\
& \text { uraian tugas } \\
\checkmark & \text { Tata tertib perkuliahan dan } \\
& \text { motivasi belajar } \\
\end{array}$ & 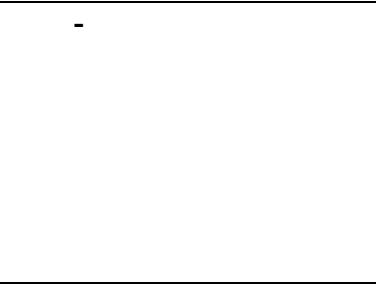 & $\begin{array}{l}\text { Pertemuan } \\
\text { Pertama } \\
(1 \mathrm{x} \\
\text { Pertemuan })\end{array}$ \\
\hline 2. & $\begin{array}{l}\text { Small Group } \\
\text { Discussion }\end{array}$ & $\begin{array}{ll}\checkmark & \text { Pengantar Sistem } \\
& \text { Akuntansi } \\
\checkmark & \text { Metodologi Perancangan } \\
& \text { Sistem Akuntansi } \\
\checkmark & \text { Sistem Pengendalian } \\
& \text { Intren (SPI) }\end{array}$ & $\begin{array}{ll}\checkmark & \text { Tanya Jawab } \\
\checkmark & \text { Tugas Tertulis } \\
\checkmark & \text { Pembuatan Simbol } \\
& \text { Flowcart dengan } \\
& \text { software komputer } \\
\checkmark & \text { Presentasi dan } \\
& \text { Diskusi } \\
\end{array}$ & $\begin{array}{l}\text { Paket Modul } \\
\text { Ajar } 1 \\
\text { (3x } \\
\text { Pertemuan) }\end{array}$ \\
\hline 3. & $\begin{array}{l}\text { Discovery Learning } \\
\text { dan } \\
\text { Pembahasan Kasus }\end{array}$ & $\begin{array}{ll}\checkmark & \text { Perancangan Formulir } \\
\checkmark & \text { Perancangan Jurnal } \\
\checkmark & \text { Perancangan Rekening } \\
& \text { Buku Besar dan Buku } \\
& \text { Pembantu }\end{array}$ & $\begin{array}{ll}\checkmark & \text { Tugas Tertulis } \\
\checkmark & \text { Kasus Terstruktur } \\
\checkmark & \text { Studi Kasus } \\
& \text { Sederhana }\end{array}$ & $\begin{array}{l}\text { Paket Modul } \\
\text { Ajar } 2 \\
\text { (4 x } \\
\text { Pertemuan) }\end{array}$ \\
\hline
\end{tabular}

37 Jurnal Akuntansi \& Manajemen Vol 10 No. 2 Desember 2015. ISSN 1858-3687 hal 29 - 39 
Perancangan Struktur Metode Student Centre Learning (SCL) Dalam Mata Kuliah Sistem Akuntansi ...

\begin{tabular}{|c|c|c|c|c|}
\hline No & Metode SCL & Materi Ajar & Format Tugas & Keterangan \\
\hline 5. & \multicolumn{3}{|c|}{ Ujian Tengah Semester (UTS) dalam Bentuk Ujian Tulis Teori dan Kasus } & $\begin{array}{l}\text { (1x } \\
\text { Pertemuan) }\end{array}$ \\
\hline 6. & $\begin{array}{l}\text { Role Play / } \\
\text { Simulation } \\
\text { dan Penjelasan } \\
\text { contoh penerapan } \\
\text { sistem akuntansi }\end{array}$ & $\begin{array}{ll}\checkmark & \text { Sistem Akuntansi } \\
& \text { Penjualan } \\
\checkmark & \text { Sistem Akuntansi Piutang } \\
\checkmark & \text { Sistem Akuntansi } \\
& \text { Penerimaan Kas }\end{array}$ & $\begin{array}{ll}\checkmark & \text { Tanya Jawab } \\
\checkmark & \text { Tugas Tertulis } \\
\checkmark & \text { Pembuatan document } \\
& \text { flowcart Sistem } \\
& \text { Akuntansi dengan } \\
& \text { software computer }\end{array}$ & $\begin{array}{l}\text { Paket Modul } \\
\text { Ajar } 3 \\
\text { ( } 2 \times \\
\text { Pertemuan) }\end{array}$ \\
\hline 7. & $\begin{array}{l}\text { Contextual } \\
\text { Instruction } \\
\text { dan } \\
\text { Pembahasan Tugas } \\
\text { Lapangan }\end{array}$ & $\begin{array}{ll}\checkmark & \text { Sistem Akuntansi } \\
& \text { Pembelian } \\
\checkmark & \text { Sistem Akuntansi Utang } \\
\checkmark & \text { Sistem Akuntansi } \\
& \text { Pengeluaran Kas }\end{array}$ & $\begin{array}{ll} & \text { Tugas Lapangan } \\
\checkmark & \text { Pembuatan document } \\
& \text { flowcart sistem } \\
& \text { akuntansi dengan } \\
& \text { software komputer } \\
\checkmark & \text { Presentasi dan } \\
& \text { Diskusi } \\
\end{array}$ & $\begin{array}{l}\text { Paket Modul } \\
\text { Ajar } 4 \\
\text { ( } 2 \times \\
\text { Pertemuan) }\end{array}$ \\
\hline 8. & $\begin{array}{l}\text { Prablem Based } \\
\text { Learning } \\
\text { dan } \\
\text { Pembahasan Kasus }\end{array}$ & $\begin{array}{ll}\checkmark & \text { Sistem Akuntansi } \\
& \text { Penggajian } \\
\checkmark & \text { Sistem Akuntansi Biaya } \\
& \text { Produksi } \\
\checkmark & \text { Sistem Akuntansi } \\
\text { Persediaan dan Aktiva } \\
\text { Tetap }\end{array}$ & $\begin{array}{ll}\checkmark & \text { Kasus Terstruktur } \\
\checkmark & \text { Pelaporan document } \\
& \text { flowcart Sistem } \\
& \text { Akuntansi dengan } \\
& \text { software komputer } \\
\checkmark & \text { Presentasi dan } \\
& \text { Diskusi } \\
\end{array}$ & $\begin{array}{l}\text { Paket Modul } \\
\text { Ajar } 5 \\
\text { ( } 4 \text { x } \\
\text { Pertemuan) }\end{array}$ \\
\hline 9. & $\begin{array}{l}\text { Ceramah dan } \\
\text { Tanya Jawab }\end{array}$ & $\begin{array}{l}\checkmark \text { Reviuw Materi Ajar untuk } \\
\text { persiapan Ujian Akhir } \\
\text { Semester (UAS) }\end{array}$ & $\begin{array}{l}\checkmark \quad \text { Latihan soal } \\
\text { komprehensif }\end{array}$ & $\begin{array}{l}\text { Pertemuan } \\
\text { Terakhir } \\
\text { (1 } 1 \text { x } \\
\text { pertemuan) }\end{array}$ \\
\hline 10. & \multicolumn{4}{|c|}{ Ujian Akhir Semester (UAS) dalam Bentuk Ujian Tulis Teori dan Kasus Terintegrasi } \\
\hline
\end{tabular}

\section{KESIMPULAN}

Penelitian ini bersifat tindakan kelas yang mengacu kepada model Kemmis dan Mac Tanggart yang dirancang ke dalam 5 tahapan utama. Penelitian ini sedang berjalan dan baru selesai pada tahap 1 yaitu perencanaan terhadap rancangan susunan model SCL dalam mata kuliah sistem akuntansi dengan KBK. Penyusunan metode SCL ini menggunakan analisis deskriptif kualitatif terhadap kesesuaian antara karakteristik metode SCL dengan sifat konten materi sistem akuntansi yang akan diajarkan dalam perkuliahan. Sehingga pada tahap 1 ini diperoleh draf rancangan susunan metode SCL dalam mata kuliah sistem akuntansi, dimana terpilih 5 metode SCL untuk digunakan dalam mata kuliah sistem akuntansi dengan KBK ini yaitu : metode Small Group Discussion, Discovery Learning, Role Play, Problem Based Learning dan Contextual Instruction.

\section{DAFTAR PUSTAKA}

Amirin, Tatang M. (2009). Classroom action research (penelitian tindakan kelas), diunduh dari http://www.tatangmanguny.files.wordpr ess.com/2009/05/kemmis-mctaggartar-cycles1.gif, Sabtu, 14 April 2012

Arifin, Samsul. 2010, P3AI-ITS, metode pembelajaran Student Centered Learning, diunduh dari http://abdulkadirsyam.wordpress.com/2 010/03/12/metode-belajar-studentcenter-learning-scl/

Arifin, Syamsul. 2010, Memahami KBK_SCL dan implementasinya. P3AI-ITS, diunduh dari http://www.vilila.com/2010/10/memaha mi-kbk-scl-dan-implementasinya.html 
Perancangan Struktur Metode Student Centre Learning (SCL) Dalam Mata Kuliah Sistem Akuntansi ...

A, Sardiman, (2001), Interaksi dan Motivasi Belajar Mengajar, Jakarta, PT Raja Grafindo Persada.

Buku Panduan Pelaksanaan Student Centered Learning (SCL) dan Student Teacher Aesthethic Role-Sharing (STAR), Pusat Pengembangan Pendidikan, Universitas Gajah Mada, 2010

Buku Panduan Pengembangan KBK Pendidikan Tinggi, Direktorat Akademik, Direktorat Jenderal Pendididkan Tinggi, 2008.

Buku Panduan Penyusunan Kurikulum Pendidikan Tinggi (KPT), Direktoran Pembelajaran dan Kemahasiswaan, Direktorat Jenderal Pendididkan Tinggi, 2012

Dewajani, Sylvi. 2008, Bahan pelatihan Kurikulum Berbasis Kompetensi (KBK) dan pemelajaran student centred Learning (SCL), Tim KBK Dikti.

Mulyadi, (2001), Sistem Akuntansi, Jakarta, Penerbit Salemba Empat.

Media Pendidikan Indonesia (2012), Desain PTK Model Kemmis \& McTaggart, Copyright : www.m-edukasi.web.id, diunduh Sabtu, 14 April 2012, di http://www.m- edukasi.web.id/2012/04/desain-ptkmodel-kemmis-mctaggart.html

Kepmen No 232/U/2000 Tentang Pedoman Penyusunan Kurikulum Pendidikan Tinggi dan Penilaian Hasil Belajar Mahasiswa

Kepmen no 045/U/2002, tentang Kurikulum Inti Pendidikan Tinggi

Perpres No. 8 Tahun 2012 tentang Kerangka Kualifikasi Nasional Indonesia (KKNI)

Rahmat, 2011, Lokakarya Pengembangan Kurikulum Berbasis Kompetensi, Universitas Diponegoro, http://eprints.undip.ac.id/28581/

Sari D, Noor Ali,2010, Pengembangan Tata Laksana Program Perkuliahan Jurusan Sistem Informasi ITS dengan metode SCL, Paper, Jurusan Sistem Informasi Fakultas Teknologi Informatika Institut Teknologi sepuluh

Unit Pengembangan Materi dan Proses pembelajaran di Perguruan Tinggi, DIKTI 2005

(http://www.cintyasantosa.cz.cc/)http:// uripsantoso.wordpress.com/category/s cl/

Undang-Undang No 20 tahun 2003 tentang Sistem Pendidikan Nasional. 